\title{
DISEASES OF MAIZE IN WAIKATO AND SOUTH AUCKLAND
}

\author{
P.G. BROADHURST \\ New Zealand Institute for Crop \& Food Research Ltd, \\ Private Bag 92169, Auckland
}

\begin{abstract}
In February-March 1996, disease surveys were conducted in several maize crops located near Hamilton, Te Awamutu and Matamata in the Waikato, and Pukekohe in South Auckland. Over 30 commercial and experimental maize hybrids were examined. Several crops were also examined in 1997 and 1998. Northern leaf blight (Setosphaeria turcica) and eyespot (Aurebasidium zeae) were the most common maize diseases encountered. Generally, the level of northern leaf blight infection in most crops did not reach economically important levels. However, a high level of infection was observed in some maize plantings at Pukekohe in 1996, and yield was subsequently affected. Although only low levels of eyespot infection were observed in most fields, the level present in some Waikato crops in 1997 was high enough to concern growers. Head smut (Sphacelotheca reiliana) was found on only a few plants located in an experimental maize plot near Pukekohe in 1996. Stalk and ear rots (Diplodia maydis, Gibberella and Fusarium spp.), and root rot (Rhizoctonia solani) levels were generally low in most crops in both the Waikato and South Auckland. Rust (Puccinia sorghi) was occasionally seen in crops in both regions but not at levels of economic importance.
\end{abstract}

\section{PHOMA DISEASE OF WASABI IN NEW ZEALAND}

\author{
P.G. BROADHURST and P.J. WRIGHT \\ New Zealand Institute for Crop \& Food Research Ltd, \\ Private Bag 92169, Auckland
}

Black markings on and in the stems of wasabi or Japanese horseradish (Wasabia japonica; Brassicaceae) can severely reduce the value of the product. In 1993-95, diseased wasabi plants were collected from a water-grown trial crop in the Waikato. Fungi and bacteria were subsequently isolated from diseased plant tissues. Phoma wasabiae was recovered from 59/84 (70\%) of leaf spot tissues, 26/85 (31\%) of blackened petiole tissues, and from 9/192 (5\%) of blackened vascular tissues found in stems. Fungi and potentially pathogenic bacteria were isolated from only $22 \%$ and $18 \%$ of blackened vascular tissues in stems, respectively. Pathogenicity tests on wasabi plants were conducted with isolates of the fungi most frequently recovered from blackened vascular tissues in wasabi stems (Plectosporium tabacinum, P. wasabiae and Phoma chrysanthemicola), Phoma lingam (the well documented "blackleg" pathogen of Brassica crops) from rape stems, and several Erwinia and Pseudomonas species recovered from wasabi stems. Leaf spots and blackened petioles only developed on plants inoculated with isolates of $P$. wasabiae (highly virulent) and P. lingam (less virulent). Dark vascular tissues were occasionally found in the stems of woundinoculated plants and were most often seen in plants inoculated with $P$. wasabiae. 